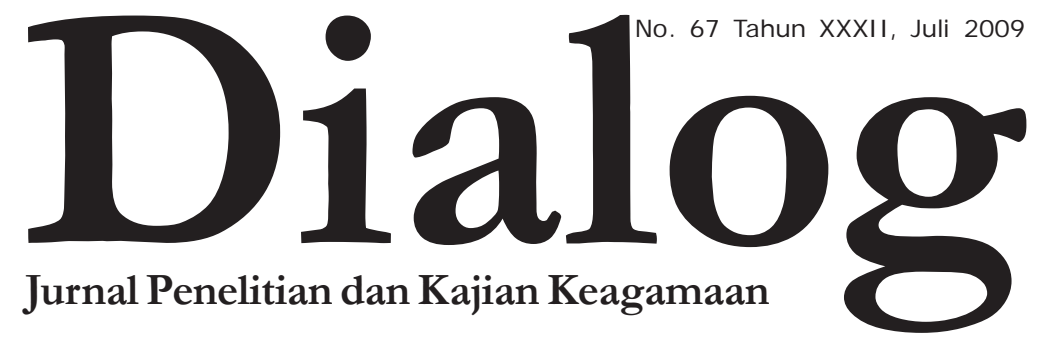

PERBANKAN SYARIAH DI INDONESIA

\begin{tabular}{|l|l|l|l|l|l|}
\hline Jurnal & $\begin{array}{l}\text { Nomor } \\
\text { Dialog }\end{array}$ & $\begin{array}{l}\text { Tahun } \\
\text { XXXII }\end{array}$ & $\begin{array}{l}\text { Halaman } \\
137\end{array}$ & Jakarta & ISSN \\
Juli 2009 & 0126-396X \\
\hline
\end{tabular}




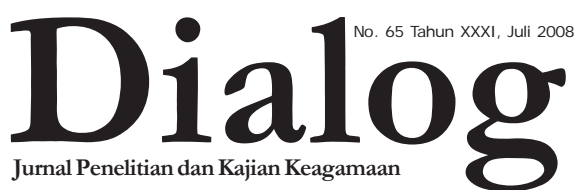

Pemi mpin Umum:

Prof. Dr. H. M. Atho Mudzhar, MA

Redaktur Aht :

Prof. Dr. H. Nasaruddin Umar, MA

Prof. Dr. H. Komarudin Hidayat, MA

Pemimpin Redaksi / Penanggung J awab

Drs. H. Syamsuddin

Waki l Pemi mpin Redaksi

H. Fanani Suprianto, SH., MM

Sekretaris Redaksi

M. Rosyid Fauzi, S.Si.

Dewan Redaksi

Prof. Dr. H. Abdurrahman Mas'ud

Drs. Amin Haedari

Prof. Dr. H. Maidir Harun

Drs. H. Mohammad Shohib, MA

Drs. H. Asmu'i, SH, MM

Chamdi Pamudji, SH., MM

Redaktur Eksekutif

M. Nasir, S.Th.I.

Redaktur Pelaksana

Moh. Rosyid Fauzi, S.Si

M. Nasir, S.Th.I

M. Adlin Sila, M.A

Abbas Jauhari, M.Ag

Admi ni strası

Drs. Dedy Curipno

Sutidjah

Desriyanti Nasution, S.IPI

Drs. H. Sahlani

Alamat Redaksi

Gedung Bayt Alquran Museum Istiqlal Komplek Taman Mini Indonesia Indah

Telp. (021) 87791444-87794982

Website:

www. balitbangdiklat.depag.go.id

Email:

info@depag.web.id

\section{PEIGITIR REDIKSL}

Karakteristik sistem perbankan syariah yang beroperasi berdasarkan prinsip bagi hasil memberikan alternatif sistem perbankan yang saling menguntungkan bagi masyarakat dan bank, serta menonjolkan aspek keadilan dalam bertransaksi, investasi yang beretika, mengedepankan nilai-nilai kebersamaan dan persaudaraan dalam berproduksi, dan menghindari kegiatan spekulatif dalam bertransaksi keuangan. Dengan menyediakan beragam produk serta layanan jasa perbankan yang beragam dengan skema keuangan yang lebih bervariatif, perbankan syariah menjadi alternatif sistem perbankan yang kredibel dan dapat dinikmati oleh seluruh

Jurnal Dialog diterbitkan oleh Badan Litbang dan Diklat Departemen Agama RI, sebagai media informasi dalam rangka mengembangkan penelitian dan kajiaan keagamaan di Indonesia. Dialog berisi tulisan ilmiah dan hasil penelitian dan pengembangan terkait dengan masalah keagamaan. Redaksi mengundang para peneliti agama, pengamat, cendekiawan, intelektual, dan akademisi untuk berdiskusi dan menulis secara bebas serta kreatif demi pengembangan penelitian maupun kajian keagamaan di Indonesia.

2 Dialog No. 67 Tahun XXXII, Juli 2009 
golongan masyarakat Indonesia tanpa terkecuali.

Fungsi Bank Syariah secara garis besar tidak berbeda dengan bank konvensional, yakni sebagai lembaga intermediasi (intermediary institution) yang mengerahkan dana dari masyarakat dan menyalurkan kembali dana-dana tersebut kepada masyarakat yang membutuhkannya dalam bentuk fasilitas pembiayaan. Perbedaan pokoknya terletak dalam jenis keuntungan yang diambil bank dari transaksi-transaksi yang dilakukannya. Bila bank konvensional mendasarkan keuntungannya dari pengambilan bunga, maka Bank Syariah dari apa yang disebut sebagai imbalan, baik berupa jasa (fee-base income) maupun mark-up atau profit margin, serta bagi hasil (loss and profit sharing).

Disamping dilibatkannya Hukum Islam dan pembebasan transaksi dari mekanisme bunga (interest free), posisi unik lainnya dari Bank Syariah dibandingkan dengan bank konvensional adalah diperbolehkannya Bank Syariah melakukan kegiatankegiatan usaha yang bersifat multifinance dan perdagangan (trading). Hal ini berkenaan dengan sifat dasar transaksi Bank Syariah yang merupakan investasi dan jual beli serta sangat beragamnya pelaksanaan pembiayaan yang dapat dilakukan Bank Syariah, seperti pembiayaan dengan prinsip murabahah (jual beli), ijarah (sewa) atau ijarah wa iqtina (sewa beli) (Farouk, 2009), dan lain-lain.
Dalam kajian Jurnal Dialog Edisi ini mencoba menyoroti perkembangan Perbankan Syariah di Indonesia yang beberapa tahun belakangan ini cukup mengalami perkembangan yang signifikan. Sehingga tidak sedikit bank konvensional yang membuka divisi syariah guna berebut nasabah yang kian meminati sistem perbankan syariah. Kajian Jurnal Dialog edisi ini diawali dengan tulisan Dr. Euis Amalia yang mengulas tentang Perbankan Syariah di Indonesia: Kontribusinya Bagi Perekonomian Nasional dan Peran Perguruan Tinggi dalam Rangka Akselerasi. Dilanjutkan dengan tulisan Muhammad Taufiki, M.Ag yang mengupas tentang Aplikasi Konsep Hilah dalam Pengembangan Produk Perbankan Syariah (Analisa terhadap Fatwa tentang Syariah Charge Card).

M. Adlin Sila, MA, peneliti di Badan Litbang dan Diklat Depag mencoba mengulas kemungkinan Bank Syariah Sebagai Bank Bagi Hasil? Ah. Azharuddin Lathif, M.Ag, MH, Dosen Fakultas Syariah dan Hukum UIN Jakarta menghadirkan tulisan tentang Analisis Yuridis Pengenaan Pajak Pertambahan Nilai (Ppn) Dalam Pembiayaan Murabahah di Perbankan Syariah. Sedangkan Prof. Dr. Abd. Rachman Mas'ud Kepala Puslitbang Kehidupan Keagamaan, melalui tulisannya mencoba menyoroti Etika Professional dan Ruh Agama di Awal Millenium. Yulizar D. Sanrego \& Aam S. Rusydiana dosen di Tazkia Institute 
menghadirkan tulisan tentang Peran Perbankan Syariah dalam Mendukung Umkm Pertanian. Kajian ini dilengkapi dengan tulisan Iyoh Masthiyah Peneliti Puslitbang Pendidikan Agama dan Keagamaan Badan Litbang dan Diklat Depag tentang Hak Milik dalam Islam Perspektif Ibn Taymiyah. Kajian dalam Jurnal Dialog edisi ini kian lengkap dengan hadirnya tulisan Yulianti Muhammad yang menganalisis Prospek Perbankan Syariah di Indonesia.

Di samping memuat artikel ilmiah, Jurnal Dialog edisi ini juga memuat laporan hasil penelitian oleh
Dr. Anwar Abbas tentang Ekonomi Islam dan Pemberdayaan Ekonomi Rakyat; Studi Kasus Pemberdayaan Melalui Koperasi Pondok Pesantren Sidogiri Kab. Pasuruan Jawa Timur. Kajian ini diakhiri dengan telaah buku yang mengulas buku karya Drs. Cik Basir, SH, MHI, 2009. Penyelesaian Sengketa Perbankan Syariah di Pengadilan Agama dan Mahkamah Syar'iyah. Semoga kajian yang dihadirkan Jurnal Dialog edisi ini memberikan manfaat yang berarti bagi para pembaca, khususnya dalam kajian Perbankan Syariah di Indonesia. Selamat Membaca!

Redaksi 


\section{DIPTIRISI}

\section{TOPIK}

PERBANKAN SYARIAH DI INDONESIA:

Kontribusinya Bagi Perekonomian Nasional dan

Peran Perguruan Tinggi dalam Rangka Akselerasi

Euis Amalia -6

APLIKASI KONSEP HILAH

DALAM PENGEMBANGAN PRODUK PERBANKAN SYARIAH

(Analisa terhadap Fatwa tentang Syariah Charge Card)

H. Muhammad Taufiki -20

BANK SYARIAH SEBAGAI BANK BAGI HASIL: MUNGKINKAH?

M. Adlin Sila -30

ANALISIS YURIDIS PENGENAAN

PAJAK PERTAMBAHAN NILAI (PPN)

DALAM PEMBIAYAAN

MURABAHAH DI PERBANKAN SYARIAH

Ah. Azharuddin Lathif -52

ETIKA PROFESSIONAL DAN RUH AGAMA

DI AWAL MILLENIUM

Abd. Rachman Mas'ud -69

PERAN PERBANKAN SYARIAH DALAM

MENDUKUNG UMKM PERTANIAN

Yulizar D. Sanrego \& Aam S. Rusydiana -74

HAK MILIK DALAM ISLAM PERSPEKTIF IBN TAYMIYAH

Iyoh Masthiyah --90

PROSPEK PERBANKAN SYARIAH

DI INDONESIA: CERAH ATAU BURAM?

Yulianti Muhammad --101

\section{PENELITIAN}

EKONOMI ISLAM DAN

PEMBERDAYAAN EKONOMI RAKYAT; Studi Kasus Pemberdayaan Melalui

Koperasi Pondok Pesantren Sidogiri Kab. Pasuruan Jawa Timur

Anwar Abbas -117

\section{BOOK REVIEW}

PENYELESAIAN SENGKETA PERBANKAN SYARIAH

(Di Pengadilan Agama dan Mahkamah Syariah)

R. Meilani Dewi - 132 


\title{
Hak Milik Dalam Islam Perspektif IBN TAYMIYAH
}

\author{
OLEH : IYOH MASTHIYAH*
}

\begin{abstract}
:
According to Ibn Taymi'yah, rights are a strength that base on syariah in the utility of an object. However, this strength is various in terms of its form and stage. At once, this strength makes an individual has the right to sell or to rent, or to present, or to lease, or to utilize for productive purposes on a condition that the right is incomplete because it is limited. Based on this view, Ibn Taymiyah devides rights in Islam into three; individual right, social right or collective, and nasional right.
\end{abstract}

\section{Pendahuluan}

Hak milik pribadi merupakan dasar dari kapitalisme, penghapusannya merupakan sasaran pokok ajaran sosialis. Pemilikan kekayaan yang tidak terbatas dalam kapitalisme pasti tidak luput dari kecaman bahwa ia turut bertanggung jawab akan kesenjangan pembagian kekayaan dan pendapatan secara mencolok, karena dalam perkembangan ekonomi sesungguhnya hampir di mana saja telah meningkatkan kekuasaan dan pengaruh perserikatan perusahaan, perusahaan yang memonopoli harga dan produksi, dan perusahaan yang

" Penulis adalah Peneliti Puslitbang Pendidikan Agama dan Keagamaan Badan Litbang dan Diklat Depag RI mempunyai hak memonopoli. Hak milik yang tidak ada batasnya ini telah membuat si kaya menjadi lebih kaya dan si miskin menjadi lebih miskin. Di sini terjadi kedaulatan konsumen, kelaliman sistem harga dan pengejaran keuntungan.

Sistem ekonomi Islam memelihara keseimbangan antara hal-hal yang berlawanan yang terlalu dilebihlebihkan. Tidak hanya dengan mengakui hak milik pribadi tetapi juga menjamin pembagian kekayaan yang seluas-luasnya dan paling bermanfaat melalui lembaga-lembaga yang didirikannya, dan melalui peringatanperingatan moral.

Tulisan ini bermaksud membahas konsep hak milik dalam Islam. Namun karena luas kajiannya dalam wacana 
fiqh, maka dipilih satu tokoh yang memiliki perhatian khusus terhadap masalah hak milik tersebut, yakni Ibn Taimiyah. Pada tulisan ini diawali dengan paparan singkat riwayat hidup Ibn Taimiyah kemudian dilanjutkan dengan paparan pandangann Ibn Taimiyah tentang konsep hak milik dan ditutup dengan kesimpulan.

\section{Riwayat Singkat IBN TAIMIYAH}

Ibn Taimiyah nama populer dari Ahmah Taqiy ad-Din Abu al-'Abbas ibn asy-Syaikh Syihab ad-Din Abiy alMahasin 'Abd al-Halim ibn asy-Syaikh Mahd ad-Din Abi al-Barakat 'Abd asSalam ibn Abi Muhammad 'Abd Allah ibn al-Qasim al-Khadlar ibn Muhammad ibn al-Khadlar ibn 'Ali ibn 'Abdullah al-Mulaqqab ibn Taimiyah. Ibn Taimiyah dilahirkan di kota Harran Mesopotamia Utara (termasuk wilayah Turki) pada 10 Rabiul Awal tahun 661 H (22 Juni $1263 \mathrm{M}$ ), sebagai putra seorang alim besar dalam mazhab Hanafi bernama Abu Muhammad 'Abd al-Halim ibn 'Abd as-Salam al-Harrani.

Ketika Harran diserang tentara Mongol pada pertengahan tahun 667 H/1270 M keluarga besar Ibn Taimiyah

1 Ibn Taimiyah, Kitab al-Asma'I wa al-Sifat, (Beirut: Dar al-Kutub al-Ilmiyah, 1408 H/1988 M), I, hlm.3; al-Syaikh Kamil Muhammad Muhammad 'Uwaidlah, Abu al-Abbas Taqiy al-Din Ahmad Ibn Taimiyah Syaikh al-Islam (Beirut: Dar al-Kutub al'Ilmiyah, 1413 H/1992 H), hlm.5; Moh. Ben Chener, "Ibn Taimiyah", Ftrst Encyclopadia of Islam (London: Luzac \& Co-Leiden:Ej.Brill, 1971), Vol. III, hlm. 951.

2 Data hari lahir Ibn Taimiyah tidak ada yang memperselisihkannya. Ia lahir pada hari Senin 10 Rabiul Awwal 661 H/22 Januari 1263 M. Selanjutnya lihat Muhammad Abu Zahrah, Ibn Taimiyah, Hayatun wa Atsaruh wa Fighuh (T.tp.: Dar al-Fikr al-Arabi, t.t.), hlm. 9-10. termasuk kedua orang tua dan tiga orang saudaranya meninggalkan kota Harran menuju kota Damaskus dan menetap di kota tersebut. Ketika itu Ibn Taimiyah baru berusia kurang lebih tujuh tahun. Peristiwa tragis yang menimbulkan kepanikan, penderitaan dan kesulitan dalam pengungsian ini sangat membekas dalam hatinya, sehingga tidak dapat dilupakan dalam ingatannya. ${ }^{3}$

Karena orang tua dan sanak saudaranya menetap di Damaskus, di tempat itu pula Ibn Taimiyah mendapatkan pendidikan. Menurut banyak sumber, Ibn Taimiyah berasal dari keluarga besar Taimiyah ${ }^{4}$ yang sangat terpelajar serta dihormati dan disegani oleh masyarakat luas pada zamannya. Ayahnya, Syihab ad-Din 'Abd al-Halim ibn-'Abd as-Salam, (627682) adalah seorang ulama besar yang mempunyai kedudukan tinggi di Masjid agung Damaskus. Ia bertindak sebagai khatib dan Imam besar masjid tersebut dan sekaligus sebagai guru dalam disiplin ilmu tafsir dan hadis. Jabatan yang juga diembannya adalah sebagai Direktur Madrasah Dar al- Hadis asSukkariyah, ${ }^{5}$ salah satu lembaga pendidikan Islam mazhab Hanbali yang sangat maju dan bermutu ketika itu. Di

3 Qomarudin Khan, Pemikiran Politik Ibn Taimiyah, terj. Anas Mahyuddin (Bandung: Pustaka, 1983), hlm. 10

${ }_{4}$ Laqob Taimiyah sebenarnya merupakan nama keluarga; yang tidak diketahui secara pasti asalusulnya, apakah dari Arab atau non-Arab. Kemungkinan mereka itu berasal dari Kurdi. Lihat Muhammad Abu Zahrah, Ibn Taimiyah, Hayatun wa Atsaruh wa Fighuh., hlm. 18; Ibn Taimiyah, Kitab alAsma'I wa al-Sifat, hlm. 5; Qomarudin Khan, Pemikiran Politik Ibn Taimiyah, hlm. 11.

5 Muhammad Abu Zahrah, Ibn Taimiyah, Hayatun wa Atsaruh wa Fiqhuh, hlm. 10

Dialog No. 67 Tahun XXXII, Juli 2009 91 
lembaga pendidikan inilah 'Abd alHalim mendidik Ibn Taimiyah.

Kakeknya, Asy-Syaikh Majd adDin Abi al-Barakat 'Abd as- Salam ibn 'Abdullah, (590-652) yang oleh Syaukani (1172-1250 H) dinyatakan sebagai mujtahid mutlak ${ }^{6}$ adalah seorang alim besar yang ahli dalam bidang tafsir, hadis, ushul fiqh, nahwu dan sebagai pengarang. ${ }^{7}$ Sedang paman Ibn Taimiyah dari pihak bapak, al-Katib Fakhruddin adalah juga seorang alim besar terkenal dan pengarang yang produktif di masanya. ${ }^{8}$ Dan Syarifuddin 'Abdullah ibn 'Abd al-Halim (696-727) adik laki-lakinya, ternyata juga dikenal sebagai ilmuwan muslim yang ahli dalam bidang Ilmu Faraid.

Selain belajar pada ayah dan pamannya, Ibn Taimiyah juga belajar dari sejumlah ulama terkenal pada masanya, utamanya yang ada di kota Damaskus dan sekitarnya. ${ }^{9}$ Sungguhpun kota ini pada saat itu keamanannya cukup terancam karena dibayang-bayangi oleh serbuan tentara Mongol, namun Ibn Taimiyah dapat belajar dengan tenang, jika dibandingkan ketika ia belajar di kota kelahirannya, Harran. Dia juga beruntung, karena sebagai pusat ilmu

6 Asy - Syaukani, Nail al-Autar Syarh Muntaqa al-Akhbar min Ahadits Sayyid al-Akhbar (Mesir: Mustafa al-Babi al-Halabi, t.t), I, hlm. 3

7 Lihat: Sa'ad Sadiq Muhammad, Ibn Taimiyah Imam al-Saif wa al-Qalam (Kairo: Majlis al-A'la li asy Syu'un al-Islamiyah, t.t), hlm. 10.

8 Muhammad Abu Zahrah, Taimiyah, Hayatun wa Atsaruh wa Fighuh, 20

9 Ibn Taimiyah, Kitab al-Asma'I wa al-Sifat, hlm. 5. Selain belajar di Damaskus, Ibn Taimiyah juga pernah menuntut ilmu di Bagdad selama enam tahun. Lihat Sa'ad Sadiq, Ibn Taimiyah Imam al-Saif wa al-Qalam, hlm. 10. pengetahuan dan pusat kebudayaan Islam, disamping Mesir, ketika itu kota Damaskus juga merupakan tempat berkumpulnya ulama-ulama besar dari berbagai mazhab atau aliran Islam pada masanya.

Studi-studi Ibnu Taimiyah tidak terbatas pada $A l-Q u r^{\prime} a n$, hadits, bahasa Arab, ilmu-ilmu Al-Qur'an, ilmu-ilmu hadits, fiqih, usul fiqh, kalam, tasawuf, filsafat, mantiq, ilmu jiwa, kesusasteraan dan matematika, melainkan secara khusus pula dia mempelajari bidang hukum mazhab Hanbali, di mana ayahnya merupakan tokoh pentingnya. ${ }^{10}$

Ibn Taimiyah sejak kecil dikenal sebagai anak yang mempunyai kecerdasan otak luar biasa, kemauan tinggi dalam belajar, tekun dan cermat dalam memecahkan masalah dan teguh dalam mengemukakan dan mempertahankan pendapat atau pendirian, ikhlas dan rajin dalam beramal saleh, rela berkorban dan siap berjuang demi kebenaran. ${ }^{11}$

Setelah memiliki ilmu yang cukup memadai, Ibn Taimiyah diangkat menjadi mufti sejak sebelum umur 20 tahun, kemudian mengabdikan ilmunya demi keluhuran Islam dan kepentingan umat Islam, baik melalui lisan dan tulisan maupun lewat lembaga pendidikan dan sarana-sarana yang lain. Sewaktu ayahnya meninggal pada tahun $682 \mathrm{H} / 1284 \mathrm{M}$ dia yang ketika itu baru saja menyelesaikan pendidikan formalnya dalam usia 21 tahun, menggantikan jabatan penting

10 Qomarudin Khan, Pemikiran Politik Ibn Taimiyah, hlm. 12

11 Lihat Muhammad 'Uwaidhlah, Abu Al-Abbas Taqiy ad-Din Ahmad Ibn Taimiyah Syaikh Al-Islam (Beirut: Dar al-Kutub al-`Ilmiah, 1413 H/1992M), hlm. 8-9

92 Dialog No. 67 Tahun XXXII, Juli 2009 
ayahnya sebagai Direktur Madrasah Dar al-Hadits as-Syukkaraniyah. ${ }^{12}$

Selain itu Ibn Taimiyah juga menggantikan kedudukan ayahnya sebagai guru besar bidang studi hadits dan fiqih madhhab Hanbali di beberapa madrasah terkenal yang ada di kota Damaskus. Kuliah-kuliahnya terfokus kepada suatu tema besar yaitu menghidupkan kembali semangat nabi dan sahabat-asahabatnya, ketika Islam belum tercemari ide-ide asing serta bid'ah dan khurafat. ${ }^{13}$

Namun perjuangan Ibn Taimiyah dalam menghidupkan kembali Islam generasi Salaf ash-shalihun, disamping mengundang kekaguman pengikutpengikutnya, juga banyak yang menentang dan memusuhi, terutama di kalangan penguasa dan para ulama' yang merasa kepentingan pribadinya terusik. Ide-idenya itulah yang menimbulkan berbagai pergolakan agama dan sosial di berbagai dunia Islam. Sebagai akibatnya, lebih dari 40 tahun lamanya Ibn Taimiyah selalu dimusuhi oleh para ulama dan penguasa. ${ }^{14}$

Untuk beberapa lama Ibn Taimiyah masih dapat mempertahankan kedudukannya sebagai ulama yang sangat dihargai serta dihormati pemerintah, bahkan dia berhasil membujuk militer supaya menumpas kaum Assasin, pengikut Ahmadiyah dan Kisrawaniyah yang memusuhinya, karena kritik keras dan serangan

${ }^{12}$ Ibn Katsir, al-Bidayah wa al-Nihayah (Beirut:

Dar al-Fikr, tt), Vol. IX, hlm. 137

13 Qomarudin Khan, Pemikiran Politik Ibn Taimiyah, hlm. 15-16

14 Qomarudin Khan, Pemikiran Politik Ibn Taimiyah, hlm. 16-20. tajamnya terhadap doktrin-doktrin mereka. ${ }^{15}$

Akan tetapi kritik-kritik kerasnya yang diarahkan kepada semua aliran atau madzhab yang ada ketika itu bahkan kadang-kadang dialamatkan juga kepada penguasa, sehingga mengakibatkan dirinya mempunyai banyak musuh dan lawan. Akibatnya posisi Ibn Taimiyah dari hari ke hari makin goyah dan akhirnya tersingkirkan, bahkan harus siap masuk keluar penjara. ${ }^{16}$

Pada mulanya keluarga ini bermukim di daerah Harran, terletak di Mesopotamia utara. Tekanan tentara Mogul yang menjarah dan menduduki daerah itu menyebabkan keluarga ini hijrah ke Damascus, ibu kota Suriah pada pertengahan tahun 1260 .

Pendidikan Ibn Taimiyah dimulai dengan belajar Al-Qur'an dan hadis pada ayahnya sendiri. Kemudian ia memasuki sekolah di Damascus, mempelajari berbagai ilmu ke-Islaman. Sejak kecil sudah tampak kecerdasan dan kejeniusannya. Dalam usia sepuluh tahun ia telah mempelajari buku-buku hadis utama, seperti kitab Musnad Ah\}mad (kitab hadis yang menghimpun hadis-hadis yang diriwayatkan oleh Imam Ah\}mad bin Hanbal), al-Kutub alSittah (Enam Kitab Hadis), Mu'jam alThabari (kamus yang dikarang oleh alThabari).

Di samping itu, ia juga belajar khat (menulis indah), ilmu hitung, menghafal Al-Qur'an dan mendalami bahasa Arab dari Ibn Abd al-Qawi.

${ }^{15}$ Qomarudin Khan, Pemikiran Politik Ibn Taimiyah, hlm. 22

${ }^{16}$ Lihat Khalid Ibrahim Jindah, Teori Pemerintahan Islam Menurut Ibn Taimiyah, terj. Mufid (Jakarta: Rineka Cipta, 1994), hlm. 23-25 
Sebagian dari ilmu-ilmu itu dapat dikuasainya dengan baik sehingga mengundang kekaguman penduduk Damascus. Ia kemudian tertarik untuk mendalami ilmu kalam dan filsafat, dan menjadi ahli di bidang keduanya. Karena ketekunan dan kejeniusannya yang luar biasa itu, ia berhasil menyelesaikan seluruh pendidikannya para usia dua puluh tahun. setahun kemudian ia diangkat menjadi guru besar hukum Mazhab Hanbali menggantikan kedudukan ayahnya yang wafat.

Ibn Tamiyah tumbuh menjadi seorang ulama terkemuka yang berpandangan luas, berpikiran rasional, dan filosofis. Ia dikenal sebagai ahli hadis, ahli kalam, fiqih, mufassir, filsuf dan sufi. Keulamaannya mencakup seluruh kajian ke-Islaman sehingga pantas mendapat gelar Shaykh al-Islam. Pada usia 30 tahun, usia yang relatif masih muda, Ibn Taimiyah sudah diakui kapasitasnya sebagai ulama besar, menandingi banyak ulama besar pada zamannya. Ibn Taymiyah kuat berpegang pada ajaran salaf.

Profesinya sebagai penulis ditekuninya sejak usia dua puluh tahun. Tulisan-tulisannya banyak bernada kritik terhadap segala pendapat dan paham yang tidak sejalan dengan pemikirannya, karena menurutnya bertentangan dengan ajaran Al-Qur'an dan hadis. Pada umumnya karya-karya Ibn Taimiyah dimaksudkan untuk memberi komentar dan kritik terhadap pendapat-pendapat para ulama semasanya maupun pendahulunya.

Sebagai penulis, ia termasuk sangat produktif. Hasil karyanya berjumlah 500 jilid, di antaranya yang terkenal adalah : [1] Kitab al-Radd 'Ala
al-Mantiqiyyin (Jawaban terhadap Para Ahli Mantik); [2] Manhaj al-Sunnah alNabawiyyah (Metode Sunnah Nabi); [3] Majmu' al Fatwa (Kumpulan Fatwa); [4] Bayan Muwafaqat Shahih al-Ma'qul Sarih al-Manqul (Uraian tentang Kesesuaian Pemikiran Yang Benar dan Dalil Naqli Yang Jelas); [5] Al-Radd 'Ala al-Hululiyah wa al-Ittihadiyah (Jawaban terhadap Paham Hulul dan Ittihad); [6] Muqaddimah fi Usul al-Tafsir (Pengantar Mengenai Dasar-Dasar Tafsir); [7] AlRadd 'Ala Falsafah Ibn Rushd (Jawaban terhadap Filsafat Ibn Rushd); [8] Al-Iklil fi al-Mutashabah wa al-Ta'wil (Suatu Pembicaraan mengenai Ayat Mutasyabih dan Takwil); [9] Al-Jawab al-Shahih li Man Baddala Iman al-Masih (Jawaban Yang Benar terhadap Orangorang Yang Menggantikan Iman terhadap al-Masih); [10] Al-Radd 'Ala alNusayriyah (Jawaban terhadap Paham Nursairiah); [11] Risalah al-Qubrusiyah (Risalah tentang Paham Qubrusiah); [12] Ithbat al-Ma'ad (Menentukan Tujuan); [13] Thubut al-Nubuwat (Eksistensi Kenabian) dan [14] Ikhlas al$R a^{\prime} i$ wa al-Ra'iyat (Keikhlasan Pemimpin dan Yang Dipimpin).

\section{Pandangan Ibn Taimiyah}

Bagi Ibn Taimiyah, hak milik adalah sebuah kekuatan yang didasari atas shari'at untuk menggunakan sebuah obyek, tetapi kekuatan itu sangat bervariasi bentuk dan tingkatnya. Misalnya, sesekali kekuatan itu sangat lengkap, sehingga pemilik benda itu berhak menjual atau memberikan, meminjamkan atau menghadiahkan, mewariskan atau menggunakannya untuk tujuan produktif. Tetapi, suatu saat tertentu, kekuatan itu tak lengkap, karena hak 
dari si pemilik itu terbatas. ${ }^{17}$ Karena itu Ibn Taimiyah membagi hak milik dalam Islam itu menjadi tiga bagian, seperti terlihat pada uraian-uraian berikut:

\section{HaK Milik Individual}

Tentang akuisisi hak milik secara individual, Ibn Taimiyah secara sederhana menjelaskan secara rinci untuk kepentingan yang dibenarkan oleh syari'at. Seperti mengamankan pemilikan suatu barang (tanah) yang terlantar karena tak memiliki pemilik jelas agar bisa terbudidayakan, pewarisan, penjualan, dan sebagainya. Setiap individu memiliki hak untuk menikmati hak miliknya, menggunakannya secara produktif, memindahkannya dan melindungi dari penyia-nyiaan (pemubaziran). Tetapi, haknya itu dibatasi oleh sejumlah limitasi. Ia tak boleh menggunakannya secara berhambur-hamburan, juga tak boleh menggunakannya semena-mena (dengan buruk) dan dilarang untuk tujuan bermewah-mewahan. ${ }^{18}$ Dalam transaksi, ia tak boleh menggunakan cara-cara yang terlarang, misalnya pemalsuan, penipuan, dan mencuri timbangan atau ukuran. ${ }^{19}$ Dalam transaksi, ia juga dilarang mengeksploitasi orang-orang yang sangat membutuhkan, misalnya dengan cara menimbun barang makanan di

${ }^{17}$ Ibn Taimiyah, Majmu' Fatawa Shaykh al-Islam Ahmad Ibn Taimiyah, Vol. 29, (Riyad: Matabi' alRiyad, 1381-1387 H), hlm. 18. Bandingkan dengan A.A. Islahi, Konsep Ekonomi Ibn Taimiyah, Terj. Anshari Tayyib (Surabaya: Bina Ilmu, 1997), hlm. 137.

${ }^{18}$ Ibn Taimiyah, Tafsir Surah al-Nur (Kairo: alMuniriyah, 1343), hlm.45.

${ }^{19}$ Ibn Taimiyah, al-H\{isbah (Kairo: Dar al-Sha'b, 1976),hlm. 22. musim kekeringan. ${ }^{20}$ Menurut Ibn Taimiyah seorang yang hanya bertujuan mengumpulkan harta kekayaan, ibaratnya seperti Qarun. ${ }^{21}$ Dan, setiap individu tidak boleh menggunakan hak miliknya, untuk tujuan yang bisa menimbulkan kerugian bagi tetangganya. ${ }^{22}$

\section{Kewajiban Pemilik}

Terpisah dengan pembatasanpembatasan atas hak milik itu, pemilik juga terkena sejumlah kewajiban tertentu. "Setiap orang itu memiliki kewajiban tertentu, misalnya membantu dirinya sendiri dan kerabatnya dan membayar sejumlah kewajiban, dan sebagainya. ${ }^{23}$ Ia menyatakan pandangannya: "Itu merupakan sebuah kewajiban pokok (fardhu 'ayn) bagi setiap individu untuk membelanjakan hartanya guna memenuhi kebutuhannya sendiri dan rumah tangganya. Sedang membantu orang miskin dan kebutuhan biaya peperangan, berpijak pada dasar kewajiban sosial (fardhu kifayah) atau sebuah amal baik yang dibutuhkan (mustahabb). Tetapi, setiap pembelanjaan untuk kepentingan umum itu menjadi kewajiban terhadap individu bila tak ada orang lain yang (mampu) melakukannya. Misalnya, memberi makan orang-orang yang kelaparan, merupakan sebuah kewajiban. $^{24}$

${ }^{20}$ Ibn Taimiyah, al-Hisbah (Kairo: Dar al-Sha'b, 1976), hlm. 24.

${ }^{21} \mathrm{Ibn}$ Taimiyah, al-Shiyasah al-Shar'iyah (Kairo:Dar al-Sha'b, 1971), hlm. 186.

${ }^{22}$ Ibn Taimiyah, Majmu' Fatawa, Vol 3I, 32-33

${ }^{23}$ Ibn Taimiyah, Majmu' Fatawa, Vol 3I ,1 30, 83

${ }^{24}$ Ibn Taimiyah, Majmu' Fatawa, Vol, 37-39 
Dalam hal bertetangga, juga terdapat kewajiban tertentu pada setiap individu, sehingga tidak dimanfaatkan oleh orang asing. Misalnya, seseorang boleh menggunakan barang apapun dari kekayaannya, jika perbuatannya itu tidak merugikan tetangganya yang lain. Bila berdampak demikian, itu sepenuhnya dilarang. Jadi, seseorang boleh mengalirkan air melalui tanah orang lain (tetangga), jika hal itu tidak merugikan pemilik tanah yang dilaluinya. ${ }^{25}$

Doktrin Ibn Taimiyah menunjukkan bahwa ia cenderung menghargai pemilikan atas harta-kekayaan yang berfungsi sosial juga. Ketika pemilik harta tidak mampu melaksanakan kewajibannya, itu tidak semata disebabkan oleh kesadaran pribadi atau personal saja. Masalahnya tidaklah begitu sederhana antara perorangan dan Allah SWT. Bisa jadi, kegagalan itu berada dalam konteks pemakluman dari masyarakat, yang membuat mereka melaksanakan sebuah perintah. Fungsi dari negara adalah untuk menata sebuah kebaikan dan melarang kecenderungan jahat. Misalnya, hak untuk menetapkan harga pasar dari barang dagangan dan mengharmonisasikan berbagai kepentingan antara produsen dan konsumen. Inilah satu di antara berbagai kasus dari intervensi negara atas hak milik pribadi. Fungsi dari pemilikan alamiah, lebih jauh didukung oleh konsep Ibn Taimiyah tentang ketetapan hukum Islami berkaitan dengan hajr (larangan). ${ }^{26}$ Yaitu, hak dari negara untuk memungut pajak di luar

${ }^{25}$ Ibn Taimiyah, Majmu' Fatawa, Vol 29, 194.

${ }^{26}$ Ibn Taimiyah, Majmu' Fatawa, Vol 3I hlm. 191.

96 Dialog No. 67 Tahun XXXII, Juli 2009 zakat dan menetapkan denda, bahkan penyitaan atas hak milik karena pertimbangan kondisi tertentu. Negara menggunakan kekuasaannya untuk melaksanakan kewajiban memantapkan perdamaian dan keadilan serta menjamin kondisi ekonomi yang berjalan baik. Negara akan memberikan beban berupa sejumlah pengeluaran kepada salah satu pihak, jika terjadi kontroversi dalam suatu masalah. ${ }^{27} \mathrm{Ibn}$ Taimiyah menganjurkan berbagai hukuman yang berbeda bagi setiap orang yang menolak melaksanakan kewajiban, padahal ia mampu memenuhinya. ${ }^{28}$ Menurutnya, "Itulah kewajiban penduduk untuk membantu yang lain yang membutuhkan roti, sandang dan tempat berteduh dan jika mereka menolak melakukannya, negara berhak mengambil langkah untuk memaksa mereka melakukannya". ${ }^{29}$ Jika seseorang yang memiliki kelebihan barang menolak meminjamkannya kepada seseorang yang membutuhkan dan penolakannya kepada seseorang yang membutuhkan dan penolakan itu bisa mengakibatkan kematian, orang itu bertanggungjawab atas terjadinya kematian tersebut. ${ }^{30}$

Ibn Taimiyah menguraikan secara detil masalah kewajiban orang mempunyai hak milik atas kewajiban memberikan pinjaman harta (al-manafi wa al-anwal) kepada lainnya dan apakah pengeluaran itu harus dilakukan secara suka rela dan untuk mencari keuntungan (bi thariq al-tabarru') atau tidak menguntungkan (bi thariq al-

${ }^{27}$ Ibn Taimiyah, Majmu' Fatawa, Vol 3I,hlm. 185

${ }^{28}$ Ibn Taimiyah, Majmu' Fatawa, Vol 3I,hlm. 186

${ }^{29}$ Ibn Taimiyah, al-Hisbah, hlm. 44.

${ }^{30}$ Ibn Taimiyah, Majmu' Fatawa, Vol 29, hlm. 189 
ta'awwud) dan dibedakannya antara yang diwajibkan dan sukarela. ${ }^{31}$ Kewajiban membelanjakan itu, bisa jadi menjadi kewajiban individual, bisa pula menjadi kewajiban sosial. Kewajiban finansial yang tak memberikan keuntungan, terbagi menjadi empat jenis. Yaitu: pembayaran zakat, menjamu tamu, menyantuni sanakkerabat, dan membantu orang yang kebetulan membutuhkan bantuan. Ibn Taymiyah menyimpulkan, keempat kewajiban tersebut merujuk pada sabda Rasulullah Saw. ${ }^{32}$

Kewajiban yang tak memberikan keuntungan adalah: berpartisipasi dalam pendidikan keagamaan, untuk amar ma'ruf nahy munkar, dan membantu orang-orang yang tertindas. ${ }^{33}$

Ada kontroversi apakah santunan kecil (amal al-ma'un) bisa dipertimbangkan dengan atau tanpa keuntungan. Ibn Taymiyah berpandangan, mereka harus melaksanakannya tanpa mempertimbangkan ongkos atau keuntungan. ${ }^{34}$ Ia lebih lanjut berpendapat, sebaiknya sejumlah barang didistribusikan tanpa bayaran apapun, misalnya untuk kepentingan manfaat umum. Tetapi, untuk kepentingan tertentu lainnya, dibutuhkan pembayaran. ${ }^{35}$ Penetapan barang yang digunakan dengan memberikan keuntungan, terbagi atas empat jenis: penetapan pertukaran barang dengan barang lain dalam

\footnotetext{
${ }^{31}$ Taimiyah, Majmu' Fatawa, Vol 29, hlm . 185190

${ }^{32}$ Taimiyah, Majmu' Fatawa, Vol 29, hlm . 190191

${ }^{33}$ Taimiyah, Majmu' Fatawa, Vol 29, hlm. 13.

${ }^{34}$ Taimiyah, Majmu' Fatawa, Vol 29, hlm . 229

${ }^{35}$ Taimiyah, Majmu' Fatawa, Vol. 31, 31-32.
}

perdagangan, pengeluaran uang untuk jasa, menukar jasa dengan uang, dan saling pertukaran yang memberikan keuntungan seperti terjadi dalam kerja sama, di mana satu pihak menyediakan tenaga dan satu pihak lagi menyediakan dananya. ${ }^{36}$ Seluruh model pertukaran seperti itu memerlukan keterlibatan kaidah agama dan tujuan keduniaan, seperti seseorang tidak bisa melakukannya sendiri dan ia terikat uluran bantuan dari pihak lain. ${ }^{37}$

Karena manusia itu secara alamiah cenderung melakukan pertukaran untuk memenuhi kebutuhankebutuhannya, syari'at tidak menetapkan paksaan, sepanjang pertukaran itu dilaksanakan secara suka rela. Jadi, dibiarkan setiap masalah diperundingkan untuk mencapai persetujuan bersama. Tetapi, ketika kesukarelaan tak tercapai, syari'at menetapkan kewajiban-kewajiban serta menetapkan tingkat pembayarannya. Misalnya, jika seseorang berutang kepada orang lain dan ia memiliki sebuah barang untuk melunasi utangnya, pemerintah bisa memaksa pengutang menjual harta miliknya dan membayar utangnya. Ini terjadi, karena pembayaran utang itu merupakan kewajiban yang tak mungkin dilunasi tanpa menjual barang miliknya. Jika pemenuhan kewajiban itu tergantung pada suatu barang, keduanya (membayar utang dan menjual barang) menjadi kewajiban. Dengan cara yang sama, pemerintah dapat mewajibkan seseorang menjual makanan dengan harga yang adil, ketika orang lain sangat membutuhkannya dan pemilik barang itu menolak menjual kecuali

${ }^{36} \mathrm{Ibn}$ Taimiyah,Ikhtiyarat, hlm. 171.

${ }^{37}$ Ibn Taimiyah, Majmu' Fatawa, Vol 28, 562. 
dengan harga yang sangat tinggi. ${ }^{38}$ Jadi, bisa dikatakan, keadilan dan kedermawanan itu berada dalam satu tangan, dibatasi secara moral dan hukum. Hak untuk menggunakan harta kekayaan secara bebas, karena harta itu merupakan anugerah (rahmat) bagi pemiliknya.

\section{HaK Milik Sosial atau Kolektif}

Tipe kedua dari hak milik adalah pemilikan secara kolektif atau hak milik sosial. Pemilikian demikian memiliki bentuk yang berbeda-beda. Misalnya, sebuah obyek bisa saja dimiliki oleh dua atau lebih orang atau oleh organisasi ataupun asosiasi. Banyak obyek tertentu dimiliki masyarakat di sebuah wilayah khusus atau oleh masyarakat seluruhnya. Hak pemilikan seperti itu, biasanya diperlukan untuk kepentingan sosial.

Jika harta kekayaan itu dimiliki oleh dua atau lebih orang, mereka bisa saja menggunakannya sesuai dengan aturan yang mereka tetapkan bersama. Tidak ada salah satu pihak dalam kerja sama tersebut boleh disakiti atau dirugikan oleh yang lain. Jika ada salah satu pihak dalam kerjasama tersebut, untuk kemanfaatan kedua pihak, pihak yang lain pun harus memberikan kontribusinya dan bekerja sama untuk itu. Fatwa Ibn Taimiyah tampak jelas dalam kasus sebuah kebun yang dimiliki oleh dua orang. Salah seorang di antara mereka ingin membangun dinding di tengah-tengah kebun tersebut, tetapi yang lain keberatan. Ibn Taimiyah memecahkan kasus itu, sehingga pihak yang menolak akhirnya bisa menerimanya. ${ }^{39}$

${ }^{38}$ Ibn Taimiyah, Majmu' Fatawa, Vol. 30, 342.
Contoh khusus tentang pemilikan harta kekayaan secara kolektif adalah wakaf. Ketika sebuah harta kekayaan disumbangkan untuk tujuan khusus atau untuk kelompok orang tertentu, ada kewajiban harta itu digunakan sesuai dengan tujuan yang ditetapkan ataupun diingini oleh orang yang dimaksud. Tetapi, Ibn Taimiyah berpendapat bahwa harta wakaf bisa diganti dengan yang lain bila memberikan manfaat lebih besar dan lebih bermanfaat untuk mencapai tujuan yang dimaksud atau orangorang yang ingin disantuni. Pandangan ini secara umum tidak diterima oleh para ahli fiqih. Ia memperbolehkan menjual sebuah pohon yang diwakafkan, yang tak pernah menghasilkan hasil panenan dan membeli pohon lain yang memiliki hasil panenan lebih baik. Pohon tak ubahnya sebuah bangunan, orang yang memperoleh amanah (wakif) memiliki hak untuk menukar atau mengubah bentuk dari obyek yang diwakafkan menjadi bentuk yang lebih menguntungkan ketimbang yang lama. Barang hasil amal atau wakaf yang digunakan oleh orang kaya, oleh Ibn Taimiyah dinyatakan tidak sah. Sebab, itu berarti merupakan penyimpangan dari perintah ajaran Islam bahwa kekayaan itu tidak boleh diperputarkan di antara orang kaya saja. ${ }^{40}$ Dengan kata lain, hal itu bertentangan dengan prinsip Islam tentang distribusi keadilan dan menutup jurang kesenjangan antara yang kaya dan miskin.

Contoh penting dari pemilikan

\footnotetext{
${ }^{39}$ Ibn Taimiyah, Majmu' Fatawa, Vol 30, 413

${ }^{40}$ Ibn Taimiyah, al-Siyasah al-Shar'iyah,hlm. 54.
} 
bersama atau sosial adalah anugerah alam, seperti air, rumput dan api, yang secara khusus disebut dalam hadis Rasul Allah saw., Salah satu alasan dari keharusan pemilikan kolektif terhadap obyek-obyek alam itu adalah, semua itu diberikan oleh Allah SWT secara gratis. Manusia tidak memiliki kesulitan apapun untuk menggunakannya. Alasan lain adalah demi kepentingan umum. Jika ada perorangan secara individual menguasainya dan memilikinya secara pribadi, hal itu bisa mengakibatkan kesulitan dan kesusahan bagi masyarakat. Menurut Ibn Taimiyah, air, rumput dan sumber api, hanyalah sebuah misal saja. Banyak obyek lain memiliki kesamaan karakteristik dengannya, yang barangkali perlu disebutkan satu-satu dalam daftar. Ia menganjurkan seluruh barang mineral yang dihasilkan oleh tanah bebas (tanah negara) menjadi milik kolektif, seperti emas, perak, garam, minyak, dan sebagainya. ${ }^{41}$

\section{HaK Milik Negara}

Kategori ketiga dari hak kepemilikan adalah hak milik negara. Negara membutuhkan hak milik untuk memperoleh pendapatan/penghasilan, sumber-sumber penghasilan dan kekuasaan untuk melaksanakan kewajiban-kewajibannya. Misalnya, untuk menyelenggarakan pendidikan, regenerasi moral, memelihara keadilan, memelihara hukum, tatanan dan secara umum melindungi seluruh kepentingan material dan spiritual dari penduduk. Menurut Ibn Taimiyah, sumber utama dari kekayaan negara adalah zakat, barang rampasan perang (ghanimah) ${ }^{42}$.

${ }^{41}$ Ibn Taimiyah, al-Siyasah al-Shar'iyah,hlm. 54

${ }^{42}$ Ibn Taimiyah, al-Hisbah, hlm. 61
Selain dari itu, negara juga bisa meningkatkan sumber penghasilannya dengan mengenakan pajak, ketika dibutuhkan dan atau kebutuhannya meningkat. ${ }^{43}$ Barang yang hilang, yang tak berhasil ditemukan siapa pemiliknya, menjadi milik negara. Hal yang sama berlaku bagi kekayaan yang tak bertuan, ${ }^{44}$ wakaf, hadiah ${ }^{45}$ dan pungutan denda, ${ }^{46}$ bisa disebutkan sebagai sumber-sumber kekayaan negara.

Kekayaan negara, secara aktual merupakan kekayaan umum (publik). Kepala negara hanya bertindak sebagai pemegang amanah (caretaker). Merupakan kewajiban bagi negara untuk mengeluarkannya guna kepentingan publik. ${ }^{47}$ Meski begitu, sangat dilarang penggunaan kekayaan negara secara berlebih-lebihan dan untuk kemubaziran. Zakat harus dibagikan kepada orang-orang yang membutuhkan (berhak menerima), sesuai dengan ajaran Islam yang ditetapkan dalam Al-Qur'an. adalah merupakan kewajiban negara untuk bekerja keras bagi kemajuan ekonomi masyarakat, mengembangkan sistem keamanan sosial dan mengurangi jurang perbedaan dalam distribusi pendapatan.

\section{Penutup}

Uraian-uraian di atas, menggambarkan kepada kita pandangan Ibn Taimiyah tentang hak milik dalam Islam. Menurut Ibn Taymiyah, hak

${ }^{43}$ Ibn Taimiyah, al-Siyasah al-Shar'iyah,34.

${ }^{44}$ Ibn Taimiyah,Majmu Fatawa, Vol. 30, 280

${ }^{45}$ Ibn Taimiyah,Majmu Fatawa, Vol. 30, 280

${ }^{46}$ Ibn Taimiyah,Majmu Fatawa, Vol. 10, 189.

${ }^{47}$ Ibn Taimiyah,Majmu Fatawa, Vol. 10, 21 
milik, adalah sebuah kekuatan yang didasari atas syari'at untuk menggunakan sebuah obyek. Seperti mengamankan kepemilikan suatu barang (tanah) yang terlantar karena tidak memiliki pemilik jelas agar bisa terbudidayakan, diwariskan, dijual belikan, dan sebagainya.

Setiap individu memiliki hak untuk menikmati hak miliknya, menggunakannya secara produktif, memindahkannya dan melindungi dari penyia-nyiaan (pemubaziran). Tetapi, haknya itu dibatasi oleh sejumlah limitasi. Inilah yang dikatakan Ibn Taimiyah sebagai hak milik individual. Tapi di samping adanya hak milik individual, dalam Islam dikenal juga adanya hak milik kolektif atau hak milik sosial. Contoh khusus tentang pemilikan harta kekayaan secara kolektif adalah wakaf.
Selain dua bentuk hak milik di atas, terdapat satu lagi bentuk kepemilikan dalam Islam yakni hak milik negara. Negara membutuhkan hak milik untuk memperoleh pendapatan/penghasilan, sumbersumber penghasilan dan kekuasaan untuk melaksanakan kewajibankewajibannya. misalnya, untuk menyelenggarakan pendidikan, regenerasi moral, memelihara keadilan, memelihara hukum dan tatanan dan secara umum melindungi seluruh kepentingan material dan spiritual dari penduduk. Menurut Ibn Taimiyah, sumber utama dari kekayaan negara adalah zakat dan barang rampasan perang (ghanimah). Selain dari itu, negara juga bisa meningkatkan sumber penghasilannya dengan mengenakan pajak, ketika dibutuhkan dan atau kebutuhannya meningkat. []

DAFTAR PUSTAKA

A.A. Islahi, Konsep Ekonomi Ibn Taymiyah, Terj. Anshari Tayyib (Surabaya: Bina Ilmu, 1997).

Ibn Taimiyah, Kitab al-Asma'i wa al-Sifat, (Beirut: Dar al-Kutub al-Ilmiyah, 1408 H/1988 M).

Syaikh Kamil Muhammad 'Uwaidlah, Abu al-Abbas Taqiy al-Din Ahmad Ibn TaYmiyah Syaikh al-Islam (Beirut: Dar al-Kutub al-'Ilmiyah, 1413 H/1992 H).

Moh. Ben Chener, "Ibn Taymiyah", Ftrst Encyclopadia of Islam (London: Luzac \& Co-Leiden:Ej.Brill, 1971), Vol. III.

Muhammad Abu Zahrah, Ibn Taymiyah, Hayatun wa Atsaruh wa Fighuh (T.tp.: Dar al-Fikr al-Arabi, t.t.).

Qomarudin Khan, Pemikiran Politik Ibn Taymiyah, terj. Anas Mahyuddin (Bandung: Pustaka, 1983).

100 Dialog No. 67 Tahun XXXII, Juli 2009
Asy - Syaukani, Nail al-Autar Syarh Muntaqa al-Akhbar min Ahadits Sayyid al-Akhbar (Mesir: Mustafa al-Babi alHalabi, t.t).

Sa'ad Sadiq Muhammad, Ibn Taymiyah Imam al-Saif wa al-Qalam (Kairo: Majlis al-A'la li asy Syu'un alIslamiyah, t.t).

Muhammad 'Uwaidhlah, Abu Al-Abbas Taqiy ad-Din Ahmad Ibn Taymiyah Syaikh Al-Islam (Beirut: Dar al-Kutub al-'Ilmiah, 1413 H/1992M).

Khalid Ibrahim Jindah, Teori Pemerintahan Islam Menurut Ibn Taymiyah, terj. Mufid (Jakarta: Rineka Cipta, 1994).

Ibn Taimiyah, Majmu' Fatawa Shaykh alIslam Ahmad Ibn Taymiyah, Vol. 29, (Riyad: Matabi' al-Riyad, 1381-1387 $\mathrm{H})$, 